\title{
RECOLLECTIONS OF EARLY TIMES IN IOWA.
}

BY C. L. LUCAS.

On the first day of October, 1853, I stood upon the bluffs that overlook the Mississippi river, from the Illinois side, and looked for the first time upen the hills that fringe a portion of eastern Iowa. The blue autumnal smoke that rested in beauty upon them, made them look both charming and majestic. I was then nearly fifteen years old, and was moving with my father and mother and the rest of our family from Indiana, to Iowa. This first sight of the State in which we expected to make our future home, only increased our desire to set our feet upon its soil and to get a more extended view of it.

We crossed the Mississippi on a ferry-boat, and first stood upon the surface of our adopted state in the town of Fort Madison. Iowa was then quite young as a State, being less than seven years old.

Fort Madison was among the first places occupied along the eastern boundary. The name was given to the military post organized there in 1808 , twenty-four years before the Black Hawk purchase was opened for settlement, and only four years after the territory contained in the State, was ceded by France to the United States. There was not a mile of railroad in Iowa at that time, but during our short stay of less than a day in Fort Madison, several steamboats landed at the wharf with cargoes and passengers. Fort Madison was at that time a supply point for a number of the inland settlements. The state penitentiary was then a small affair, but even in that early day it contained a number of convicts.

The next town we reached was West Point, once the county seat of Lee county. It was here that Steven and William Hodges were tried, convicted, and hung, in 1845, for the murder of Miller and Liecy, on May the 10th of 
that year. Liecy was a son-in-law of Miller, and both families had just removed to the State. They lived in the same house on a farm near West Point. As they wished to buy a good farm, it was supposed that they had money, and this led to the attempted robbery and murder. The Hodges lived at Nauvoo, in Illinois; they belonged to the Mormon church, and to a band of thieves that operated over a broad expanse of country. These were the only executions that took place during Iowa's territorial period. A complete history of this affair is given in Edward Bonney's "Banditti of the Prairies."

West Point was a nice little town about ten miles north of Fort Madison and situated near the breaks of the Mississippi bills.

The next town on our route was Salem, in the southwest corner of Henry county. We had now passed from the Mississippi hills and found the country more level, but by no means a flat country in general.

Salem was at that time a station on the underground railroad, and this fact made it a historic place. It had been settled by the abolitionists during the fifties. They had taken an oath never to obey the fugitive slave law, and if the stories told of their doings about the time we passed there were true, they had not violated their oaths. At this place many a negro found shelter and rest, while escaping from bondage to freedom. The abolitionists were much censured then, but when we look back over those times it now seems that theirs was the true and correct course to take.

From Salem we took the old Fort Madison and Agency City road, and went northwest, intending to travel along the divide between the Des Moines and Skunk rivers. The distance from Salem to Agency City is forty-five miles. It took us three days to make this distance, for Iowa had taken one of her weeping spells, which continued for three days, and this gave some of us the blues. One man of our party 
who lost his enthusiasm when the rain came, said that nature was bewailing onr fate, and was shedding copious tears for us. The rain made the hill sides slippery, and the level land muddy and soft. In many places we had to double teams which made traveling slow and tedious. But we found the people along the route kind and willing to furnish shelter when asked to do so.,

We reached the historic town of Agency City all right and there concluded to rest for one day. At that time it was a place much talked about, but now it is seldom mentioned.

The Sac and Fox agency was established there in 1838, and Gen. Joseph M. Street, the Agent at Prairie du Chien, was transferred to the new agency. From 1838 to 1843 the Agency was the only place west of the Black Hawk Purchase, where a white man dared to dwell.

Gen. Street died there May 5̆th, 1840, and was buried near the Agency. Just two years from that time Chief Wapello died, and in accordance with his request he was buried by the side of Gen. Street, for whom he cherished much friendship. We visited their graves and read the inscriptions on the slabs that marked them.

On the morning of the 7 th of October, 1853, we left Agency City over the old stage route by way of Oskaloosa, Pella and Tool's Point to Fort Des Moines. The weather was nice again, the sun shone brightly, and the autumnal smoke once more rested in beauty upon the surrounding hills and elevations. This gave us all courage and we - pressed on anxiouns to reach the end of our journey.

The country between Agency City and Oskaloosa looked inviting, and we found the people kind and obliging. Even in that early day Oskaloosa was a town of more importance than any we had passed through since leaving Fort Madison. At that time its chief boast was that it contained the largest distillery in the State. This was before any law regulating the sale of intoxicating liquors had been placed upon the 
statute books. A distillery in that day was looked upon as valuable property, but at the present, such property is outlawed. Such is the difference in public sentiment, which fifty years of time has brought about.'

The next place on our route was the Holland town of Pella. Here for the first time in our lives we saw people wearing wooden shoes; here too for the first time we saw stove pipes extending through thatched grass-roofed houses. From this place on to the end of our journey sod houses were frequently seen; while they did not look inviting on the outside, they were very comfortable on the inside during the storms of winter. There is no better or more fertile country than that around Pella.

We were not long in traveling the short distance from Pella to Tool's Point, for the roads were now good, and the country was fairly level. Tool's Point was but a small village with its few houses nestled along the south side of a point of timber. It was a place frequently spoken of, for the reason that there was no other town along the military road and stage route, between it and Fort Des Moines, a distance of thirty miles. Here we purchased some bread and drove on about five miles where we camped for the night, turning our oxen out to graze upon the grass which was yet green.

It never once occurred to any of us that we had camped upon historic ground that evening, nor did we know anything of this until we were so informed by a gentleman living near-by, who came to visit with us after supper. From him we learned that we were camped on the site selected six years prior to that time, for the new state capital, by a commission appointed for the purpose. This commission selected five sections of land, laid out a town and sold 415 lots. One of these commissioners, more enthusiastic than the rest, bought 38 of the lots, for which he paid $\$ 6.50$ each. The name of the new capital was Monroe City.

At the next session of the legislature the doings of this 
commission were set aside, the money paid on the lots was refunded to the purchasers, and the prospective state capital died in its infancy. Instead of a great city springing up on these five sections of land in Jasper county, as the commissioners fondly hoped to see, they are now divided into fine farms.

As soon as it was known that the new capital movement was defeated, Tool's Point appropriated the name, which still lives, not as the name of a capital city, but a town of prominent mention in the State.

Although I was only a boy at the time, I listened with much interest to the verbal sketch given by our visitor, and have since then found that it corresponds with the facts of history.*

This man also related at the time, a very singular coincidence in the location of two places, which has since been corroborated. $\dagger$ When Mr. William Highland, the first settler at Tool's Point drove up and halted at the point of timber to begin the erection of the first log cabin built at the place, he looked over toward the Des Moines river and saw the stars and stripes floating in the breeze and going up stream. This at the time was a great surprise to him, but he afterwards learned that the flag was hoisted over the little steamer Ione, which was then carrying Captain Allen, and the first installment of troops up the river to the Raccoon fork, to locate Fort Des Moines.

The next morning, October the 10th, we started early intending to get over as many miles of the remaining journey as possible. We had traveled but a short distance when we met some five families who had spent the summer in Boone county, and who had become so completely disgusted with the country, that they were returning to eastern Illinois. They tried very hard to persuade my father to go no further, but he frankly told them that he was headed for

*House Journals of 1846 and 1848.

†Andreas' Historical Atlas, Chicago, 1875. 
Boone county, and there he intended to go. This brought the conversation to a close, and we drove on.

That day we crossed several small streams, among which were Mud Creek, and Four Mile Creek, which rendered the country a little rolling but did not detract from its beauty or its desirability for good homes. In the evening just before sundown we arrived near Fort Des Moines and camped on a bill that overlooked the embryo city. This hill was near where the capitol building now stands. Fort Des Moines was then a small place, about all the houses, both business and residence, being contined to the grounds of the old military post. The only outlook it had for making a city of importance was the prospective coming of the state capital. All believed, and fully believed, that the capital was sure to come. But they were not alone in this belief; the people all along the roads over which we had traveled, from Fort Madison to Fort Des Moines, believed, conceded and most of them advocated the same thing.

It was not the people of Fort Des Moines that brought the state capital there; it was the people of the eastern and southeastern parts of the State. This is evidenced by th $\theta$ fact, that when the final action was taken to move the state capital from Iowa City to Fort Des Moines, January 25, 1855 , out of the sixty-four members composing the house of representatives of that session, fifty of them were from the eastern and southeastern parts of the State.* In fact it will have to be admitted that it was the people of the eastern and southeastern parts, that nurtured Iowa from its territorial birth to full fledged statehood, and started it on its first era of prosperity.

On the morning of October 11, we applied some tar to the skeins of our old-fashioned linchpin wagons, the only kind in use at that time, and left the future state capital grounds, by way of Saylor's bottom, Montacute, Polk City and the old Twenty-mile House, and camped at Swede

*House Journal, 1855. 
Point just over the line in Boone County. There were two small $\log$ houses at the point at that time. Not one of us supposed that night that we were camped on a future town site, but we were. The spot on which we camped that evening is now within the corporate limits of Madrid, a town of 1200 people, the present home of the writer.

After looking around for about a week my father located four miles southeast of Boonesboro, then the county seat of Boone county, but now the fifth ward of Boone. On one forty of the land my father purchased, there was a log house and attached to it was an old-fashioned stick and clay chimney. The house was $16 \times 20$, and contained but one room. It seems incredulous that a good sized family wintered in that house, but such is the fact. There was room enough in the loft for two beds, and they were reached by climbing up a roughly made ladder. Be assured that it took a great amount of fuel to keep warm in that log house when the blizzards came, and that was quite often in those days.

On more than one morning during that winter, we awoke to find two inches of snow on the bed covers, and all over the loft, which the wind had driven during the night through the crevices of the clapboard roof. To step from a warm bed into this snow, and descend upon the ladder to the lower floor, and fill up the fireplace with wood, was a thing that tried the soul of a fifteen year old boy.

This was a rough quality of pioneer experience on the border settlements of Iowa. It is not to be wondered at that the pioneers have good memories.

We were all glad when spring came, for everything then looked brighter. Improving a farm and erecting better buildings for the next winter was now the animating thought, and we went to work with a courage that never fails to bring results. We carried on farming, breaking prairie, and hauling goods from the Mississippi river towns, a distance of two hundred miles.

For breaking prairie we received from $\$ 2.00$ to $\$ 2.50$ 
per acre. From three to five yokes of oxen were hitched to a 20-inch plow, and would break from two to three acres of sod per day. For hauling goods for the merchants, we received $\$ 2.50$ per hundred pounds. It took twenty days to make a trip with an ox team, and fifteen days with a horse team. For several years most of the hauling was done with ox teams, because they lived upon the grass of the open country, while a horse team had to be supplied with costly feed.

From two to four teams usually went at the same time from the same place, for no teamster had any desire to make a four-hundred mile trip alone. After being on the road a few days, we would meet loaded teams returning to various places, and would fall in with others going after loads. Sometimes a dozen teamsters would camp at the same place, and then there would be a jolly time.

In the fall of 1855 , fourteen loaded teams camped on the present site of the town of Prairie City. Nearly all the country about there was open at that date, making it a good place to turn our oxen out upon the grass. Among those teamsters was Captain J. M. Stallsworth of Adel. He had a very heavy wagon with wide tires and a very large box; this wagon was drawn by four yokes of oxen, and it contained six thousand pounds of whiskey, brandy and wine.

This was during the time the first prohibitory law in Iowa was in force. It was passed January 22, 1855. By its terms no person was allowed to sell intoxicating liquors in any county in the State except agents duly appointed by the county judge. These agents had power under the law to buy and sell intoxicating liquors for medical, mechanical, and sacramental purposes. The agent in Dallas county had hired Captain Stallsworth to haul this mammoth load of liquors to supply the trade of his agency. From the plight the captain was in on the evening just referred to, he either had other liquors along with him or else he was patronizing the agency before the goods reached their destination. 
This law was very unpopular; so much so, that it was repealed January 28, 1857, after being on the statute book two years and six days.

In the early settlement of Iowa everybody wanted to locate on the edge of the timber. When we arrived all these locations were taken, and perforce of circumstances, we had to seek a location a mile out from the timber. Our house was the farthest out on the prairie; some people prophesied that we would freeze to death, while others said they could not be hired to live out there. We paid no attention to this talk for we knew that the deep rich soil of the prairie had not been made for nothing. There was a rudely built school house down on the timber line a mile and a half from us. Here I attended school for the first time in Iowa. Our teacher was a graduate from a Pennsylvania college. He was a fine scholar and a good man; his name was Thomas Sparks, and he is still living. He came to Boone county in 1847, and at the organizing election held in August, 1849, he was chosen Connty Surveyor. He is the only survivor of the nine officers first elected in the county and is now eighty-eight years old.

From our home on the prairie we could look for miles in the blue distance without seeing a house, a tree, a fence or a cultivated acre. All of those broad acres could then be bought for $\$ 1.25$, each. But now how great is the contrast. Over this same expanse of country, beautiful homes, groves and farms, join one to another like a vast checkerboard, and not an acre can be bought for less than $\$ 80.00$.

At that time there was not a rod of railroad in the State, but now there is a railroad station on my father's farm, and within a short distance from his residence. Such is the wonderful contrast that the progress of fifty years has brought about.

Madrid, Iowa, February, 1904. 
Copyright of Annals of Iowa is the property of State of Iowa, by \& through the State Historical Society of Iowa and its content may not be copied or emailed to multiple sites or posted to a listserv without the copyright holder's express written permission. However, users may print, download, or email articles for individual use. 